\title{
Advanced Manufacturing Technology: Defining the Object and positioning it as an Element of Manufacturing Strategy
}

\author{
Dr. Amit Kumar Bansal \\ Professor \& Director, JB Institute of Technology, Dehradun \\ Sumit Sangwan \\ Assistant Professor, Department of Mechanical Engineering, JB Institute of Technology, Dehradun \\ Ravi Shankar \\ Assistant Professor, Department of Mechanical Engineering, JB Institute of Technology, Dehradun
}

\begin{abstract}
Advanced Manufacturing Technologies (AMT) represent an opportunity for manufacturing firms to improve their competitiveness. In spite of the breadth of literature on the subject, there is a substantial divergence of opinion on what may be considered AMT, and how they may be classified. To confront this issue, the paper presents a review of literature and discusses the existing concepts in AMT research. The paper proposes a definition of AMT which is useful as a means to understanding the boundaries of AMT and discusses various forms of classification. Once the object is defined, AMT is demonstrated as part of Manufacturing Strategy.
\end{abstract}

Key-words: Advanced Manufacturing Technologies, Manufacturing Strategy

\section{INTRODUCTION}

Advanced Manufacturing Technologies (AMT) are widely considered as competitive weapon that can be used by enterprises seeking to improve their competitiveness (SMALL, 1993; TRACEY et al., 1999; etc.), particularly because they are related to 'operations', which are believed to be a source of sustainable competitive advantage (HAYES and UPTON, 1998). In the particular case of Brazil, the industrial capability demands investments in technology (FLEURY and FLEURY, 1997), a fact that is becoming increasingly critical because of the 'threats' faced by local companies as a result of globalization (FLEURY, 1999). A discussion concerning AMT is becoming lively once again. This is evident from the frequency of publications in Journals, after a decline in importance during the mid-90. The issue of confronting AMT as an element of strategy is 'currently receiving much scholarly attention' (adapted from KOTHA and SWAMIDASS, 2000). The literature on AMT is very wide and deals with different aspects related to the adoption and implementation of AMT - for example, related factors such as strategic planning, technology consistency, work preparation for AMT adoption etc. (SMALL and YASIN, 1997). The majority of articles, however, discuss AMT related issues without providing a definition, or describe AMT by use of examples (AMT, that encompass technologies such CNC, CAD) (e.g. VOSS, 1986; TRACEY et al., 1999; BURCHER and LEE, 1997; BOYER, 1998; SAMBASIVARAO and DESHMUKH, 1995; MILLEN and SOHAL, 1998). This results in difficulties for defining the boundaries of what constitutes AMT. For example, just-in-time (JIT) is considered as AMT by some authors although it is not traditional manufacturing 'equipment'. There has been a major technological development since the term 'AMT' was first utilized. A contributing factor in defining AMT is associated to the meaning of 'advanced' (i.e. what is 'advanced' then may no longer be 'advanced' now). In addition to technological advances there has also been advancement in concepts: at the end of the 70s and until the mid-80s, at least from the occidental point of view, automation was considered a new pattern of leading production systems (BESSANT, 1994). 'Lean' production systems, however, became the new paradigm due to the success of Japanese industries and the interest shown by MIT researchers through the publication of 'The machine that changed the world' (WOMACK et al., 1990). One then might ask if an ASRS (automatic storage and retrieval system) should be considered as 'advanced' technology, since from the 'one piece flow' concept, the production systems do not have to have inventories. As discussed by other authors (BRANDYBERRY et al., 1999; KOTHA and SWAMIDASS, 2000), we accept that a definition for AMT is needed, and their classifications must be assessed. The definition has to be expansive enough to accommodate the latest technological developments, and restrictive enough 
to impose boundaries for what the acronym AMT encompasses. With this purpose, the concept of 'Advanced Manufacturing Technology' is discussed and a definition is presented. After making the definition, we examine various forms of classification found in literature and demonstrate how some AMT fit with those classifications. Once the object is defined, we position AMT as an element of strategy, through the manufacturing function. This paper draws on the research to develop an operational framework for the selection of AMT, by using a similar approach to manufacturing audits (PLATTS, 1990). Due to limitations of space, selections of results from the literature review are presented.

\section{EXPLORING THE CONCEPT OF AMT}

The concepts found in the literature, in general, associate AMT with computer based and numerical controlled systems. These concepts regard such 'technologies' as flexible due to their 'programmable' nature. The following examples represent this view:

- Advanced Manufacturing Technology represents a wide variety of modern computer-based or numerical control-based systems devoted to the improvement of manufacturing operations. An AMT consists of varying combinations of hardware and software components, with some form of computerized or numerical control. Some AMT such as CAD and CAPP are software based with computerized control, while Numerical Controlled (NC) machining centers consist of predominantly hardware components controlled by numerical commands (SMALL, 1993).

- AMT is a piece of programmable machinery or a system of programmed machines that can produce a variety of products or parts with virtually no time lost for changeovers from one product to the next' (GROOVER, 1987)

- AMT are generally defined as systems providing flexibility as well as data driven computer integration for manufacturing organization' (HUNT, 1987 apud LIN and NAGALINGAM, 2000).

The definitions are vague without a clear explanation of what one means by 'modern', 'advanced' or 'technologies', 'manufacturing processes and operations' and 'manufacturing organizations'. With the view to defining AMT, we will discuss the meanings of 'manufacturing', 'technology' and 'advanced' within the context of AMT. It is important to note that this paper will not explore these concepts in detail: they will only be reviewed with the purpose of presenting a definition. In our understanding, manufacturing is broader than that proposed by LIN and NAGALINGAM (2000) and WU (1994): 'the organized process whereby products are made or created by various production activities from raw material'. We adopt Singh's (SINGH, 1996) description: 'manufacturing is a series of interrelated activities and operations involving design, material selection, planning, production, quality assurance, management, and marketing of discrete consumer and durable goods'. The extension of the earlier description goes beyond the manufacturing process itself, but is concerned with the entire manufacturing organisation (where one of its goals is the manufacture of products). On the definition of technology one can attach many different meanings, from etymological to nature of application. In the Cambridge International Dictionary of English (CAMBRIDGE, 1995) we find the following definition: '(the study and knowledge of) the practical, esp. industrial, use of scientific discoveries'. From this definition one can observe the looseness of the concept. FORD and SAREN (1996) in their work dealing with technological audits, show that even managers of the enterprises have difficulties in understanding what technology means to them. McLOUGHLIN and CLARK (1994), by reviewing work by various authors, present many definitions for technology. They range from ones which are more restricted (i.e. that defines technology as equipment and apparatus) to other which elaborate such as that by WINNER (1977), who defines technology from three dimensions: apparatus, referring to the equipment itself; technique, referring to the skills and knowledge necessary to use the equipment; and organisation, referring to systems and structures of control and coordination. If we were to accept a broad definition, we could consider JIT as an manufacturing technology, since it is based on a method of controlling material flow (a 'technology') to improve manufacturing operations. Because of the looseness of the definition, we will adopt to a more restrictive definition of technology, i.e. equipment and apparatus (including hardware and software) used within a manufacturing organisation. The other mis-used term is 'advanced'. Within the field of AMT research, the term does not mean 'upto-dated technology', nor the most recent knowledge or way of organising the production system. 'Advanced' only refers to the industrial development phase that technologies belong to: the first phase was primary mechanisation, where water and steam were employed in substitution of the man's manual work when producing; then the secondary mechanisation applied machines powered by electricity to produce goods, encompassing the productive process itself, including the transfer and assembly; and the tertiary mechanisation, or the 'new industrial revolution', that makes use of microelectronic based technologies with high information processing capabilities to co-ordinate and control the 
transfer and transformation activities (McLOUGHLIN and CLARK, 1994; WU, 1994). Based on the above discussions, an Advanced Manufacturing Technology can be viewed as encompassing the computer and numerical based apparatus (software and hardware) designed to accomplish or support manufacturing tasks. This definition excludes 'managerial technologies' but may include, for instance, information networks for shop-floor data.

\section{AMT CLASSIFICATIONS AND DEVICES}

The literature presents different classifications for AMT, depending on the particular aspect under consideration (e.g. functionality or level of integration). We will present and discuss some of the most import or recent classifications found. A well accepted classification was developed by the US Department of Commerce in 1988 (US, 1989). They group the technologies by functionality: 1) design and engineering; 2) fabrication / machining and assembly; 3) automated material handling; 4) automated inspection \& testing system; 5) communications \& control. ADLER (1988) presents a similar classification: a) design automation; b) manufacturing automation; c) administrative (or control) automation. SOHAL (1997) classifies the AMT by the nature of the apparatus, into three groups: a) computer hardware; b) computer software; c) plant and equipment. MEREDITH and SURESH (1986) divide AMT based on their level of integration, in technical terms: stand alone, linked

(intermediate) and integrated. SMALL and YASIN (1997) use a classification that incorporates two dimensions: the functionality (US, 1989) and the level of integration (MEREDITH and SURESH, 1986). Their broad definition regard JIT as a type of AMT. BRANDYBERRY et al. (1999), on the other hand, classify how well AMT will foster organisational integration, and not at the level of integration of the technologies involved: a) stand-alone AMT; b) functionally oriented AMT; c) CIM (computer integrated technology). The authors' approach imply that although CAD/CAM may be fully integrated, they only promote integration between the design and production sectors, that is, the integration is still restricted to the 'manufacturing area' of the company, and for this reason they are considered collectively as functionally orientated AMT. KOTHA and SWAMIDASS (2000), highlight the need for including the information processing capabilities in addition to the level of flexibility. They propose: a) information exchange and planning technologies; b) product design technologies; c) high-volume automation technology; d) low-volume flexible automation technology. Table 1 presents the above classifications and relates each subclassification to the author and to some AMT often found in the literature and at manufacturing organisations. Through Table 1 one can observe that each AMT is sometimes classified into different categories, or even into the sub-categories with a particular category. To assess which classification is more consistent than the other is not an easy or simple task: it depends on the purpose of the classification. 
Table I: AMT and their classifications

\begin{tabular}{|c|c|c|c|c|c|c|c|c|c|c|c|c|c|c|c|c|c|c|c|c|c|c|}
\hline \multicolumn{23}{|c|}{ AUTHOR } \\
\hline US depet. Of oommetce (1959) & & & & $\nabla \mid$ & $\nabla$ & & $\nabla \mid$ & $\nabla$ & & & & $\nabla$ & & & & & & & & & & \\
\hline ADI.ER (1938) & & & & 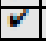 & $\nabla$ & & & & & & $\nabla$ & & & & & & & & & & & \\
\hline SOHAL. (1997) & & & & & & & & & & & & & $\nabla$ & V & $\nabla$ & & & & & & & \\
\hline MEREDTTH and SURESSH (1936) & 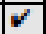 & $\nabla$ & $\nabla$ & & & & & & & & & & & & & & & & & & & \\
\hline SMAII and YASIN (1997) & $\nabla$ & $\nabla$ & $\nabla$ & 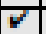 & $\nabla$ & $\nabla$ & $\nabla$ & $\nabla$ & 醇 & 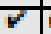 & $\nabla$ & & & & & & & & & & & \\
\hline BRANDYBERRY of $\alpha .(1999)$ & & & & & & & & & & & & & & & & 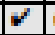 & 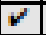 & 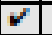 & & & & \\
\hline KOTHA and SWAMIDASS $(2000)$ & & & & & & & & & & & & & & & & & & & $\nabla$ & $\nabla$ & $\nabla$ & $\boldsymbol{v}$ \\
\hline \multirow{2}{*}{$\begin{array}{l}\frac{Z}{0} \\
\frac{2}{3} \\
\frac{3}{3} \\
\frac{3}{3}\end{array}$} & \multicolumn{3}{|c|}{ 할 } & \multicolumn{9}{|c|}{ 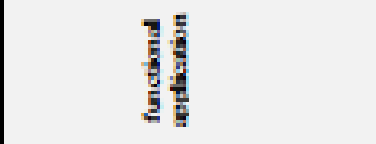 } & \multicolumn{3}{|c|}{ 量 } & \multicolumn{3}{|c|}{ 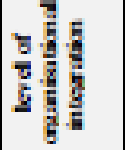 } & \multicolumn{4}{|c|}{ 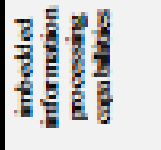 } \\
\hline & 造 & $\begin{array}{l}\frac{8}{2} \\
\frac{2}{2} \\
\frac{2}{2}\end{array}$ & 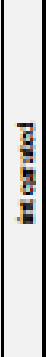 & 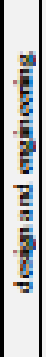 & 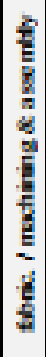 & 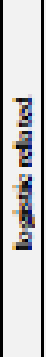 & 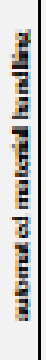 & 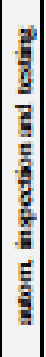 & 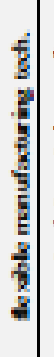 & 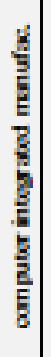 & 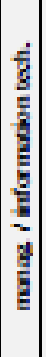 & 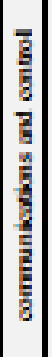 & 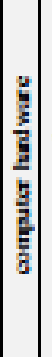 & 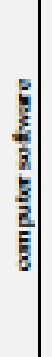 & 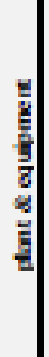 & 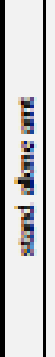 & 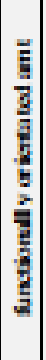 & z) & 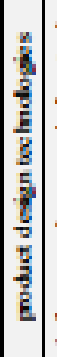 & 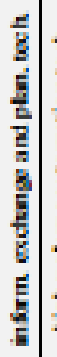 & 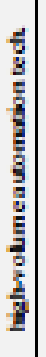 & 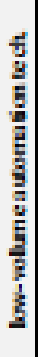 \\
\hline NC-mimetically cantrol & $\checkmark$ & & & & $\checkmark$ & & & & & & & & & & & & & & & & & $\vec{v}$ \\
\hline CNC - compul, numetical control & $\nabla$ & & & & $\nabla$ & & & & & & & & & & $\nabla$ & $\nabla$ & & & & & & v \\
\hline 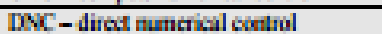 & $\nabla$ & & & & $\nabla$ & & & & & & & & & & & & & & & & & \\
\hline CAD - compuler aided design & $\nabla$ & & & 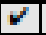 & & & & & & & & & & $\bar{V}$ & & $\nabla$ & & & $\nabla$ & $\nabla$ & & \\
\hline 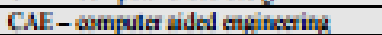 & & & & $\nabla$ & & & & & & & & & & & & & & & $\nabla$ & $\nabla$ & & \\
\hline CAM - coenpuler a ided manulac. & & & & $\checkmark$ & & & & & & & & & & 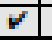 & & & $\checkmark$ & & & & & $v$ \\
\hline CAPP - compaided proess planting & $\nabla$ & & & $\nabla$ & & & & & & & & & & & & & & & & & & \\
\hline MRP - malerial fequirement glanting & $\nabla$ & & & & & $\nabla$ & & & & & & & & $\nabla$ & & & & & & $\nabla$ & & \\
\hline $\begin{array}{l}\text { MRP II - manufacturing fewoukes } \\
\text { plaraing }\end{array}$ & & 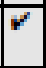 & 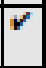 & & & & & & & & $\bar{V}$ & & & $\vec{v}$ & & & & & & $\nabla$ & & \\
\hline $\begin{array}{l}\text { AGVVIAGVS - waloen, guidal vethicle } \\
\text { sylen }\end{array}$ & & & & & & & 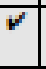 & & & & & & & & 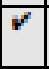 & $\nabla$ & & & & & & \\
\hline Rotos (genetal) & $\nabla$ & & & & $\nabla$ & & & & & & & & & & $\nabla$ & $\nabla$ & & & & & $\nabla$ & \\
\hline Rick and Face Rebots & $\nabla$ & & & & $\nabla$ & & & & & & & & & & & & & & & & $\nabla$ & \\
\hline 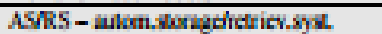 & & $\nabla$ & & & & $\nabla$ & $\nabla$ & & & & & & & & $\nabla$ & $\nabla$ & & & & & & \\
\hline AMHS - aubom mat. handing sex & & 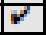 & & & & $\nabla$ & & & & & & & & & & & & & & & & \\
\hline FAS - flevilye aseermbly svalens & & & & & $\checkmark$ & & & & & & & & & & $\nabla$ & & & & & & & \\
\hline $\begin{array}{l}\text { ATS - Auwemulic irspectice and leslify } \\
\text { sye. }\end{array}$ & & $\nabla$ & & & & & & $\nabla$ & & & & & & & $\nabla$ & & & & & & $\nabla$ & \\
\hline 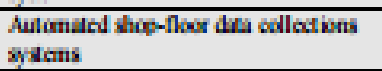 & & & & & & & & & & & & & $\nabla$ & & & & & & & & & \\
\hline FMC - Resbils manufucturing cals & & & $\nabla$ & & $\nabla$ & & & & $\nabla$ & & & & & & $\nabla$ & & & & & & & \\
\hline FMS - flexible muruf, systems & & & 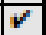 & & $\nabla$ & & & & 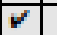 & & & & & & 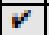 & & $\mathbf{v}$ & & & & & $\bar{v}$ \\
\hline CIM-campulet inl, manufacluring & & & $\nabla$ & & & & & & & $\bar{T}$ & & & & & & & & 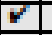 & & & & \\
\hline FLC- prostam. logic controlles & 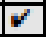 & & & & & & & & & & & 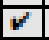 & & & & & & & & & & \\
\hline LAN - local arta netuok - digid VO & & & & & & & & & & & & $\nabla$ & $\boldsymbol{V}$ & & & & & & & $\nabla$ & & \\
\hline LAV - local afth netwok - meseafei & & & & & & & & & & & & $\nabla$ & $\mathbf{v}$ & & & & & & & $\nabla$ & & \\
\hline WAN - wilc afea tetwork & & & & & & & & & & & & & $\boldsymbol{v}$ & & & & & & & 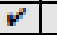 & & \\
\hline Duta base minagement sysem & & & & & & & & & & & & & & $\bar{V}$ & & & & & & & & \\
\hline
\end{tabular}

For purchasing or inventory purposes, the SOHAL's (1997) classification may be useful. For organization design, considering the role of the technologies, the classification proposed by BRANDYBERRY et al. (1999) may represent a valuable tool. MEREDITH and SURESH's (1986) classification no longer seem to be applicable, since the advances in microelectronics and information processing and interchange, are making the technologies completely integrated - some of them can be applied in a standalone way, but this does not mean that the technology itself is stand alone. When selecting AMT, the identification of the objectives that will lead to an acquisition of an 
advanced technology is cardinal and from those objectives one can find the more suitable classification. For instance, if one of the main reasons to acquire an AMT is to promote inter-functional integration, the BRANDYBERRY et al.'s classification seems to be appropriate. Otherwise, if more 'operational' results are expected, the functional application (and the consideration of the information processing capability) appear to be more suitable.

\section{AMT AS AN ELEMENT OF THE ENTERPRISE’S STRATEGY}

HOFER and SCHENDEL (1978) identified three main levels of strategy: corporate (what set of business should we be in?); business (how should we compete in XYZ business?); and the functional strategy (how can the function contribute to the competitive advantage of the business?). Since the seminal work from Skinner (SKINNER, 1969), much attention have been paid to the manufacturing function. The manufacturing strategy 'defines how [the] manufacturing [function] will assist in the achievement of the business objectives through the provision of appropriate structural items (buildings, plant and equipment, etc.), and the appropriate infrastructure (manning, organization, control policies, etc.) to ensure that operations are effective' (PLATTS and GREGORY, 1990). The manufacturing literature may be divided into two components: the process and the content of the manufacturing strategy. Content can be captured in two broad categories: the decision areas and the manufacturing objectives (LEONG at al., 1990). The understanding of competitive priorities or manufacturing objectives may vary slightly among authors, but cost, quality, time, flexibility and innovativeness may be considered as such (BUFFA, 1985; HILL, 1993; SLACK, 1993; BOLWIJN and KUMPE, 1990; etc.). AMT can contribute significantly to the achievement of manufacturing objectives. For example, through the use of CAM, the company can offer better and improved product quality (Quality) and provide faster response to customers (Time). The use of CAPP can lead to a reduction of the new product lead-time (Time), as well as reduces new part introduction costs (Cost) and reduces process planning time and set up and toll design time (Cost, Time). The decision areas represent the areas within which decisions are made to achieve the business goals (SKINNER, 1969; HAYES and WHEELWRIGHT, 1984). The latter divide and define two sets of decision areas: structural 'because of their long-term impact, the difficulty of reversing or undoing them once they are in place, and the fact that substantial capital investment is required to alter or extend them', and the infrastructural, 'that encompass myriad ongoing decisions; they are linked with specific operating aspects of the business; and they generally do not require highly visible capital investments' (p.31). We have chosen to adopt the decision areas proposed by MILLS et al. (1996) (Table 2). Therefore AMT affect manufacturing strategy from the perspective of 'manufacturing process technology' decision area. That is, they represent a domain of choices (or decisions) through which the manufacturing goals can be achieved and even exceeded.

Table 2 - Manufacturing Strategy's decision areas

\begin{tabular}{|c|c|}
\hline \multicolumn{2}{|l|}{ Structural docision aroas } \\
\hline Capacily & Capacity fexibility, shift pattems, temporary subconiracing policies \\
\hline Faclines & The size, locaion and foos of manudacturing resources \\
\hline Mandlacturing process: technology & 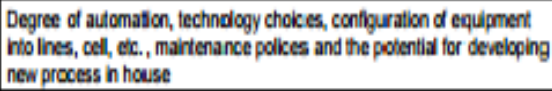 \\
\hline Vertical integration & $\begin{array}{l}\text { Stralegic makeversus-buy decisions, supplier polidies, edent of } \\
\text { dependence of supdiers }\end{array}$ \\
\hline \multicolumn{2}{|l|}{ Intrastructural docision aroas } \\
\hline Organisation & Stucture, accountatellites and responsiblifies \\
\hline Quality policy & Quallity assurance and quality control policies and practices \\
\hline Producion control & Production and material contral sysiems \\
\hline Human resouroes & Recoulhment, training and development, oulture and managemert style \\
\hline New product introbuction & $\begin{array}{l}\text { Design for manufacturing gudeline, introduction stages, organis ational } \\
\text { apects }\end{array}$ \\
\hline Performance messurement and reward & $\begin{array}{l}\text { Financial and non-financial performance management and linikges io } \\
\text { recognition and reward systems }\end{array}$ \\
\hline
\end{tabular}

Source: (adapted from HAYES and WHEELLRIGHT, 1984 and MILLS et al., 1996)

The implementation of AMT affect many of the other strategic decisions areas. For example, CAM can reduce floor space requirements (Facilities) and improves quality, affecting the Quality decision area. Since new skills are required from the workers, it also affects the Human Resources area. CAPP increases the capacity utilisation (Capacity) and reduces new product design lead time and process planning time, that have an impact on the New Product Introduction decision area. An automated assembly system may provide better product quality with higher 
levels of consistency and uniformity (Quality), reduces floor space requirements (Facilities), and provides efficient production scheduling (Production Control). A list of general or individual benefits of AMT may be found, for instance, in work by SMALL (1993); LIN and NAGALINGAM (2000); MACHUCA (1995); BUCHER and LEE (1997).

\section{FURTHER WORK AND CONCLUSIONS}

This paper presented a number of outcomes from a wider research concerned with developing a process approach for selecting AMT, considering then as a decision area of a manufacturing strategy, in the manner of the manufacturing audits (PLATTS, 1990; PLATTS, 1993). The process of selection of AMT needs to take into account both the benefits to the achievement of the manufacturing objectives and the impacts on the decision areas. This literature review resulted in a restricted definition for AMT, which may be used as a means to develop boundaries and exclude other technologies that do not fall within the definition. A discussion about current AMT classifications was made and AMT were regarded as elements of manufacturing strategy, taking into account manufacturing objectives and the impacts on the other decision areas. The final research outcome - an operational tool for AMT selection - is intended to be useful for both users and suppliers of such technologies, especially in emerging countries like Brazil, that have to utilise their industrial sectors as a weapon (GOUVEA DA COSTA and FLEURY, 1999) to cope with the new challenges imposed by the current fierce competitive environment.

\section{REFERENCES}

[1] ADLER, P.S. Managing flexible automation. California Management Review, vol. 30, n. 3, p. 34-56, 1988.

[2] BESSANT, J. Towards total integrated manufacturing. International Journal of Production Economics, vol. 34, p.237-251, 1994.

[3] BOLWIJN, P.T.; KUMPE, T. Manufacturing in the 1990s - productivity, flexibility and innovation. Long Range Planning, p. 44-57, vol.23, n.4, 1990.

[4] BOYER, K. Longitudinal linkages between intended and realized operations strategies. International Journal of Operations \& Production Management, vol.18, n. 4, p. 356-373, 1998

[5] BRANDYBERRY, A.; RAI, A.; WHITE, G. Intermediate performance impacts of advanced manufacturing technology systems: an empirical investigation. Decision Sciences, vol. 30, n. 4, p.993-1020, 1999

[6] BUFFA, E S. Meeting the competitive challenge with manufacturing strategy. National Productive Review, spring, p. 155-169, 1985

[7] BURCHER, Peter G.; LEE, Gloria L. The challenge of investing in advanced manufacturing technologies: a study of British manufacturers. Research Report Aston Business School, Birmingham, 1997.

[8] CAMBRIDGE. Cambridge international dictionary of English. Bath : Cambridge Press, 1995

[9] FLEURY, A. The changing pattern of operations management in developing countries: the case of Brazil. International Journal of Operations \& Production Management, vol.19, n. 5/6, p. , 1999.

[10] FLEURY, A. FLEURY, M. T. L.. Aprendizagem e inovação organizacional: as experiências de Japão, Coréia e Brasil. 2. ed. São Paulo : Atlas, 1997.

[11] FORD, D.; SAREN, M. Technology strategy for business. London : ITBP, 1996

[12] GOUVÊA DA COSTA, Sérgio E.; FLEURY, Afonso. Strategic flexibility as a key weapon in a competitive environment: a brief study applied to the brazilian machine-tools industry. PORTLAND INTERNATIONAL CONFERENCE ON MANAGEMENT OF ENGINEERING AND TECHNOLOGY - PICMET’99 (1999 : Portland). Portland, Oregon, USA, 1999.

[13] GROOVER, M.P. Automation, production systems, and computer integrated manufacturing. Englewood Cliffs : Prentice-Hall, 1987.

[14] HAYES, Robert H.; WHEELWRIGHT, Steven C. Restoring our competitive edge: competing through manufacturing. New York : John Wiley \& Sons, 1984.

[15] HAYES, R. H.; UPTON, D. Operations-based strategy. California Management Review, vol. 40, n. 4, p. 8-25, summer, 1998.

[16] HILL, T. Manufacturing strategic role. Journal of the Operational research Society, vol. 34, n. 9, p.853-860, 1983

[17] HOFER,C.W.; SCHENDEL, D. Strategy formulation: analytical concepts. St. Paul : Wets Publish., 1978 HUNT, D.V. Dictionary of advanced manufacturing technology. New York : Elsevier, 1987

[18] KOTHA, S.; SWAMIDASS, P. Strategy, advanced manufacturing technology and performance: empirical evidence from US manufacturing firms. Journal of Operations Management, vol. 18, n.. 3, p. 257-277, 2000.

[19] LEONG, G. K.; SNYDER, D.L.; WARD, P.T. Research in the process and contend of manufacturing strategy. OMEGA International Journal of Management Science, vol. 18, n.2, p.109-122, 1990.

[20] LIN, G.; NAGALINGAM, S. CIM justification and optimisation. London : Taylor \& Francis, 2000

[21] MACHUCA, J.A.D. (Coord.) Dirección de operaciones: aspectos estratégicos em la producción y los servicios. Madrid : McGraw-Hill, 1995

[22] McLOUGHLIN, I.; CLARK, J. Technological change at work. 2nd. Edition. Buckingham : Open University Press, 1994

[23] MEREDITH, J.; SURESH, N. Justification techniques for advanced manufacturing technologies. International Journal of Production Research, vol. 24, n. 5. p. 1043-1058, 1986.

[24] MILLEN, R.; SOHAL, A. Planning process for advanced manufacturing technology by large american manufacturers. Technovation, vol. 18, n. 12, p.741-750, 1998

[25] MILLS, J.; PLATTS, K.; NEELY, A.; RICHARDS, H.; GREGORY, M; BOURNE, M.. Creating a winning business formula. Swanley : Findlay Publications, 1996

[26] PLATTS, K. A process approach to researching manufacturing strategy. International Journal of Operations \& Production Management, vol.13, n. 8, p. 4-17, 1993

[27] PLATTS, K. Manufacturing audit in the process of manufacturing formulation. Ph.D. Thesis, University of Cambridge, UK, 1990

[28] PLATTS, K.; GREGORY, M. Manufacturing audit in the process of strategy formulation. International Journal of Operations \& Production Management, vol.10, n. 9, p. 5-26, 1990 
[29] SAMBASIVARAO, K.V.; DESHMUKL, S.G. Selection and implementation of advanced manufacturing technologies: classification and literature review of issues. International Journal of Operations \& Production Management, vol.15, n. 10, p. 43-62, 1995.

[30] SINGH, N. Systems approach to computer-integrated design and manufacturing. New York : John Wiley \& Sons, 1996.

[31] SKINNER, W. Manufacturing - missing link in corporate strategy. Harvard Business Review, may./jun, p.136-145, 1969.

[32] SLACK, N. Vantagem competitiva em manufatura: atingindo competitividade nas operações industriais. Tradução Sonia Maria Correa. São Paulo : Atlas, 1993.

[33] SMALL, M. Towards successful implementation of advanced manufacturing technology: a process-factors-process approach. Ph.D. Thesis, Cleveland State University, USA, 1993

[34] SMALL, M.; YASIN, M. Advanced manufacturing technology: implementation policy and performance. Journal of Operations Management, vol. 15, n.. 4, p. 349-370, 1997.

[35] SOHAL, Amrik S. A longitudinal study of planning and implementation of advanced manufacturing technologies. International Journal of Computer Integrated Manufacturing, vol.10, n. 1-4, p. 281-295, 1997

[36] TRACEY, M.; VONDEREMBSE, M.A.; LIM, J. Manufacturing technology and strategy formulation: keys to enhancing competitiveness and improve performance. Journal of Operations Management, vol. 17, n.. 4, p. 411-428, 1999

[37] US DEPARTMENT OF COMMERCE. Current industrial reports: manufacturing technology 1988. SMT (88) - 1, Bureau of Census, May, 1989.

[38] VOSS, C.A. implementing manufacturing technology: a manufacturing strategy approach. International Journal of Operations \& Production Management, vol.6, n. 4, p. 17-26, 1986.

[39] WINNER, L. Autonomous technology. Cambridge , MA : MIT Press, 1977

[40] WOMACK, J.; JONES, D.; ROOS, D. The machine that changed the word. New York, Macmillan, 1990.

[41] WU, $\begin{array}{lllllll}\text { B. Manufacturing systems design and analysis. 2nd edition. London } & \text { Chap }\end{array}$ man \& Hall, 1994 